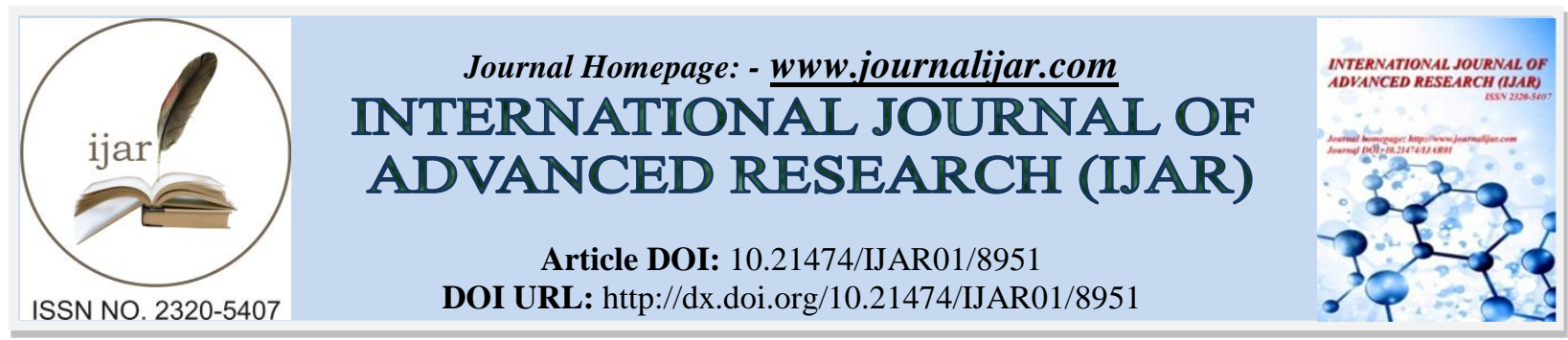

RESEARCH ARTICLE

\title{
BUSINESS ENVIRONMENT AND INVESTMENT CLIMATE IN THE REPUBLIC OF UZBEKISTAN.
}

\section{Islambek Rustambekov ${ }^{1}$ and Abduaziz Isakulov ${ }^{2}$.}

1. Doctor of Sciences in Law, Head of Department at Ministry of Justice of Uzbekistan.

2. Leading Consultant at Ministry of Justice of Uzbekistan.

\section{Manuscript Info}

Manuscript History

Received: 22 February 2019

Final Accepted: 24 March 2019

Published: April 2019

Key words:-

business environment, foreign investment, investment climate, legal regime.

\begin{abstract}
in the article current conditions and recent reforms that have been made in Uzbekistan with regards to business environment, investment climate and trust of foreign investors toward country's efforts were explored and analyzed. Moreover, particular positive expertise of foreign countries including some countries of Central Asian region which can be implemented by Uzbekistan in near future in the course its further reforms are discuss.
\end{abstract}

Copy Right, IJAR, 2019,. All rights reserved.

\section{Introduction:-}

A favorable investment climate is a prerequisite for stably developing economic development, attracting investments to regions and industries, and boosting entrepreneurial activity. It promotes investment in important production and social projects, expands the possibilities for innovation, improves the quality of economic and social development.

In 2017, the share of foreign direct investment in total investment in Uzbekistan amounted to 20.4\%, with an increase of $40.7 \%$ from the previous year. In terms of capital intensity, calculated by international experts, Uzbekistan is an attractive country for foreign direct investment. The Republic is among the countries that in 2016/2017 achieved the best results in improving business performance through regulatory reforms aimed at improving the business environment. However, the country's rating values for a number of indicators are not high enough, which reduces the investment activity of investors and in the context of the reorientation of world players from investing in new production projects, a particularly negative impact on the reorganization and restructuring of business. Thus, the current conditions of the global investment policy require significant efforts to attract investment in developing economies, including Uzbekistan, by creating the most favorable investment climate.

The quality of the investment climate in the country potential investors usually monitor, studying the data of various analytical, research companies and agencies. The World Bank's Doing Business rating is widely known among them. Rating indicators reflect the level of development of the business environment, the advancement of the process of creating in various countries the internal conditions necessary for doing business and attracting investments. A high rating of the business environment means that the country has created the most favorable conditions for economic development.

In its report "Doing Business 2018", the International Finance Corporation has published ratings on business favoring in 190 countries of the world. According to the indicator of ease of doing business, Uzbekistan ranks 74 out of 190 (in 2013 - 154 out of 185). Among the countries of Europe and Central Asia - 19 out of 24 (in 2013 - 24 out

Corresponding Author:- Islambek Rustambekov.

Address:-Doctor of Sciences in Law, Head of Department at Ministry of Justice of Uzbekistan. 
of 24). It can be easily seen a huge breakthrough made by the country in less than five years in improving the business environment and investment climate.

This was facilitated by large-scale work to reduce the time of paperwork and their number, reduce the costs associated with these procedures, thanks to the organization of "single window" services, reorientation of credit institutions to more fully meet the needs of small and private businesses, liberalization of the foreign exchange market, information and communication technologies in the activities of government bodies, etc. Indicative results of the work done to improve the rating of the taxation indicator, which takes into account taxes and mandatory deductions, as well as the administrative burden on enterprises. If in the ranking of 2013 on this indicator, the country ranked 161 , in the ranking of 2018 - already 78 place.

Uzbekistan has a substantial body of laws and regulations aimed at protecting the business and investment community. Primary legislation regulating competition includes the Law on Competition and Restrictions of Monopolistic Activity (2016), the Law on Competition, the Law on Guarantees of the Freedoms of Entrepreneurial Activity, the Law on Private Enterprise (2003, last updated in 2017), the Law on Investment Activities, and a number of decrees, resolutions and instructions.

In late 2016, the government of Uzbekistan publicly recognized the need to improve and streamline business and investment legislation, which is still perceived to be complicated, often contradictory, and not fully consistent with international norms. In some cases, the government may require businesses to comply with decrees or instructions that are not publicly available. To avoid problems with tax and regulatory measures, foreign investors often secure government benefits through Cabinet of Ministers decrees, approved directly by the president. These, however, have been easily revocable.

According to the report, Uzbekistan ranked 76th (74 last year) among 190 countries. The indicator of ease of introducing business in the country was 67.4 (66.33). At the same time, Uzbekistan ranked 12th among the countries of the world in terms of "Registration of enterprises", "Connection to the power supply system" - 35, "Enforcement of contracts" - 41, "Obtaining loans" - 60, "Protection of minority investors" - 64, "Taxation" - 64, Registration of property" - 71, "Resolution of insolvency" - 91, "Obtaining building permits" - 134 and "International trade" 165.

For comparison, we study one of the developed countries on the rating of "Doing Business". For instance, Singapore maintains an open, heavily trade-dependent economy, characterized by a predominantly open investment regime, with strong government commitment to maintaining a free market and to actively managing Singapore's economic development. The World Bank's Doing Business 2017 report ranked Singapore as the world's second-easiest country in which to do business. The Global Competitiveness Report 2017-2018 by the World Economic Forum ranked Singapore as the third-most competitive economy globally. Singapore typically ranks as the least corrupt country in Asia and one of the least corrupt in the world, and actively enforces its robust anti-corruption laws.

Singapore's legal framework and public policies are generally favorable toward foreign investors. Foreign investors are not required to enter into joint ventures or cede management control to local interests, and local and foreign investors are subject to the same basic laws. Apart from regulatory requirements in some sectors (reference Limits on National Treatment and Other Restrictions), the government screens investment proposals with the purpose of determining eligibility for various incentive regimes. Singapore places no restrictions on reinvestment or repatriation of earnings or capital. The judicial system, which includes international arbitration and mediation centers and a commercial court, upholds the sanctity of contracts, and decisions are generally considered to be transparent and effectively enforced.

Another country occupying the top line in the rating of "Doing Business" is South Korea. The Republic of Korea offers a stable and largely open environment for investment; however, in certain sectors, "Korea-unique" regulations that do not align with global standards continue to create market barriers. The Republic of Korea has made tremendous economic gains during the past six decades, transforming from a recipient of foreign assistance to a high-technology manufacturing powerhouse and middle-income donor nation. The country experienced real GDP growth of 3.1 percent in 2017, up from 2.7 percent growth in 2016. Economic growth in 2017 was mainly driven by an increase in global demand, particularly in electronics. The Bank of Korea, in its latest forecast, projects growth to remain strong in 2018 at 3.0 percent, driven by increased domestic demand and continued growth in exports. Long- 
term growth projections, however, remain moderate (between 2 to 3 percent) due to The Republic of Korea's relatively developed economy, aging population, and inflexible labor market. Concerns also remain that a global trend towards monetary policy normalization could push the BOK to raise interest rates, which would tamp down consumption, hurting growth. The Republic of Korea government's attitude toward FDI is positive, and senior policymakers realize the value of foreign investment. Following the 2008-2009 global financial crisis, inbound FDI has trended upwards from USD 5.4 billion in 2010 to USD 12.8 billion in 2017 . However, foreign investment in The Republic of Korea is still, at times, hindered by insufficient regulatory transparency, including inconsistent and sudden changes in interpretation of regulations, as well as underdeveloped corporate governance structures, high labor costs, an inflexible labor system, and market domination by large conglomerates, known as chaebol.

The Foreign Investment Promotion Act (FIPA) is the basic law pertaining to foreign investment in The Republic of Korea. FIPA and related regulations categorize business activities as open, conditionally or partly restricted, or closed to foreign investment. The Republic of Korea prioritizes investment retention, in part through a Foreign Investment Ombudsman. The position is commissioned by the President and heads a grievance resolution body that: collects and analyzes information concerning problems foreign firms experience; requests cooperation from and recommends implementation of reforms to relevant administrative agencies; proposes new policies to improve the foreign investment promotion system; and carries out other necessary tasks to assist investor companies.

Kazakhstan is a neighboring country, but the investment climate is rationally different from Uzbekistan. While Kazakhstan's vast hydrocarbon and mineral reserves remain the backbone of the economy, the government continues to make incremental progress toward its goal of diversifying the country's economy by improving the investment climate. Kazakhstan's efforts to remove bureaucratic barriers - including through a new "single window" - have been moderately successful and the World Bank in 2018 ranked the country 36 out of 190 in its annual Doing Business Report.

The government maintains an active dialogue with foreign investors, through President Nazarbayev's Foreign Investors Council, the Prime Minister's Council for Improvement of the Investment Climate, and the Investment Ombudsman.

Kazakhstan joined the WTO in 2015 and began to lift local content requirements per its WTO accession commitments. In June 2017, Kazakhstan joined the OECD Declaration on International Investment and Multinational Enterprises and became an associated member of the OECD Investment Committee.

Turkmenistan is a physically large country but is sparsely inhabited (about 5 million people), with abundant hydrocarbon resources, particularly natural gas. Turkmenistan's economy depends heavily on the production and export of natural gas, oil, petrochemicals and, to a lesser degree, cotton, wheat, and textiles. According to the 2017 Statistical Yearbook of Turkmenistan, the country's Gross Domestic Product (GDP) was USD 36.18 billion in 2016 , USD 35.8 billion in 2015, and USD 43.5 billion in 2014. Official figures for 2017 are not yet available. The government reported an implausibly high GDP growth of 6.2 percent in 2017 and 2016. The economy actually appears to have been in recession since the last quarter of 2014 when global hydrocarbon prices fell. Food inflation hovered around 36 percent in Ashgabat in 2017.

On February 5, 2019, the President of the Republic of Sh. M. Mirziyoyev issued a resolution on additional measures to improve the rating of the Republic of Uzbekistan in the annual report of the World Bank and the Doing Business International Finance Corporation. On the basis of the resolution the procedure was approved according to which target indicators for improving the rating of the Republic of Uzbekistan in the annual report of the World Bank and the Doing Business International Financial Corporation provide for the Republic to achieve 20th place in the rating by 2022 - "Improving Business Management - 2022".

In addition, a number of preferences to attract foreign investors and support national ones have been established. As the head of state noted, "Only by actively attracting investments, by introducing new production capacities, we can achieve accelerated development of our economy. And the positive results in the economy would allow us to consistently solve the accumulated problems in the social sphere." 
Mutually beneficial cooperation with foreign partners is convincing, since sufficient conditions have been created in Uzbekistan to strengthen the confidence of foreign investors. The state investment policy of the country is designed for the long term and is aimed at creating all the necessary conditions for the effective work of investors.

However, in order to promote more effective attraction and further allocation of foreign direct investment funds into the country, implementing effective realization of Rule of Law principle and strengthening the trust of foreign investors, there a lot of things to be done in Uzbekistan in near future.

But the main thing, there are all prerequisites for Uzbekistan to be successful and investment friendly country: a favorable geographical position, a developed transport network, the availability of sufficient and highly efficient natural resources, a high level of development of the production and social infrastructure, qualified personnel and other factors that could allow investors to look far into prospective future as well as favorable business and investment climate. 